\title{
Pharmaciana
}

Vol.10, No.2, July 2020, Page. $147-156$

ISSN: 2088 4559; e-ISSN: 24770256

DOI: $10.12928 /$ pharmaciana.v10i2.13010

\section{Antioxidant and antiaging activity of rutin and caffeic acid}

\author{
Ermi Girsang*1, I Nyoman Ehrich Lister ${ }^{1}$, Chrismis Novalinda Ginting1, \\ Ika Adhani Sholihah ${ }^{2}$, Martinus Ahmad Raif ${ }^{1}$, Sidharta Kunardi ${ }^{1}$, \\ Hendy Million', Wahyu Widowati ${ }^{3}$ \\ ${ }^{1}$ Faculty of Medicine, Universitas Prima Indonesia, \\ Jl. Belanga No. 1 Simp. Ayahanda, Medan, 20118, North Sumatera, Indonesia \\ ${ }^{2}$ Biomolecular and Biomedical Research Center, Aretha Medika Utama, \\ Jl. Babakan Jeruk II No. 9, Bandung, 40163, West Java, Indonesia \\ ${ }^{3}$ Faculty of Medicine, Maranatha Christian University, \\ Jl. Surya Sumantri No. 65 Bandung, 40164, West Java, Indonesia
}

\begin{abstract}
Aging is a complicated process occurring due to the combination of incremental alterations of the skin and accumulated extrinsic factors that causes both structural and functional disruptions. The extrinsic factor of skin aging is mostly caused by free radicals, UV exposures, and pollution. Prevention is possible by escalating antioxidant intake to scavenge ROS in the skin aging process. Rutin and caffeic acid are recognized for their free radical trapping effects and reported to have potential antiaging activities. This study aimed to identify the potentials of rutin and caffeic acid as antioxidant and antiaging. Rutin and caffeic acid were tested for their antioxidant properties using the DPPH, $\mathrm{H}_{2} \mathrm{O}_{2}$, ABTS radical scavenging, and FRAP assays. Meanwhile, their antiaging activities were examined by collagenase, elastase, hyaluronidase, and tyrosinase inhibitory assays. The study drew on the evidence of antioxidant and antiaging properties from the scavenging, ferric ion reducing, and inhibitory activities of rutin and caffeic acid (in ascending order): in scavenging DPPH free radicals $\left(\mathrm{IC}_{50}\right.$ of rutin $=5.79 \mu \mathrm{g} / \mathrm{mL}, \mathrm{IC}_{50}$ of caffeic acid $\left.=8.72 \mu \mathrm{g} / \mathrm{mL}\right)$, scavenging $\mathrm{H}_{2} \mathrm{O}_{2}\left(\mathrm{IC}_{50}\right.$ rutin $=12.09$ $\mu \mathrm{g} / \mathrm{ml}, \mathrm{IC}_{50}$ caffeic acid $=15.23 \mu \mathrm{g} / \mathrm{mL}$ ), reducing ABTS $\left(\mathrm{IC}_{50}\right.$ caffeic acid $=6.23 \mu \mathrm{g} / \mathrm{mL}, \mathrm{IC}_{50}$ rutin $=$ $16.59 \mu \mathrm{g} / \mathrm{mL}$ ), reducing ferric ions at $50 \mu \mathrm{g} / \mathrm{mL}$ (FRAP of rutin $=480.08 \mu \mathrm{M} \mathrm{Fe}(\mathrm{II}) / \mu \mathrm{g}$, FRAP of caffeic acid $=526.50 \mu \mathrm{M} \mathrm{Fe}(\mathrm{II}) / \mu \mathrm{g})$, inhibiting collagenase $\left(\mathrm{IC}_{50}\right.$ caffeic acid $=74.42 \mu \mathrm{g} / \mathrm{mL}, \mathrm{IC}_{50}$ rutin $=104.70 \mu \mathrm{g} / \mathrm{mL}$ ), inhibiting elastase $\left(\mathrm{IC}_{50}\right.$ rutin $=46.88 \mu \mathrm{g} / \mathrm{mL}, \mathrm{IC}_{50}$ caffeic acid $=76.95 \mu \mathrm{g} / \mathrm{mL}$ ), inhibiting tyrosinase $\left(\mathrm{IC}_{50}\right.$ rutin $=55.65 \mu \mathrm{g} / \mathrm{mL}, \mathrm{IC}_{50}$ caffeic acid $=145.91 \mu \mathrm{g} / \mathrm{mL}$ ), and inhibiting hyaluronidase $\left(\mathrm{IC}_{50}\right.$ rutin $=114.07 \mu \mathrm{g} / \mathrm{mL}, \mathrm{IC}_{50}$ caffeic acid $\left.=244.45 \mu \mathrm{g} / \mathrm{mL}\right)$. Rutin and caffeic acid have the potentials as antiaging and antioxidant.
\end{abstract}

Keywords: rutin, caffeic acid, antioxidant, antiaging

\footnotetext{
*Corresponding author:

Ermi Girsang

Faculty of Medicine, Universitas Prima Indonesia

Jl. Belanga No. 1 Simp. Ayahanda, Medan, North Sumatera, Indonesia

Email: ermigirsang@unprimdn.ac.id
} 


\section{INTRODUCTION}

Aging is a normal multifactorial pattern that catalyzes physical changes in skin and connective tissue (Farage et al., 2009; Widowati et al., 2016, 2017, 2018). Such physiological changes occur as a result of intrinsic aging and cumulative extrinsic damage, such as UV exposures (Widowati et al., 2017), pollution (Riani et al., 2018), and free radicals (Widowati et al., 2016, 2017, 2018). Free radicals are known to induce oxidation of nucleic acid, proteins, and lipids, harm intracellular structures including nuclear factor-kappa B (NF-kB), DNA, and Activator protein (AP-1), and upregulate intracellular transcription factors. AP-1 is responsible for the formation of matrix metalloproteinases (MMPs), which crushes existent collagen and, consequently, forms crease. Damages due to reactive oxygen species (ROS) lead to excessively produced melanosomes and weakened elastin_(Palmer and Kitchin, 2010).

Collagen, hyaluronic acid (HA), elastin, and tyrosine are some of the proteins affected by aging (Taofiq et al., 2016; Widowati et al., 2018). Collagen is a major component that builds and maintains skin elasticity and strength. It is the main element of connective tissue, nails, and hair (Widowati et al., 2016, 2017, 2018). Elastin is a protein of the extracellular matrix (ECM) that contributes to the elasticity of connective tissues (Onar et al., 2012). Melanin or tyrosine is a major pigment responsible for skin color. Increased tyrosinase activity during the aging process leads to hyperpigmentation (Taofiq et al., 2016). Hyaluronic acid plays a part in preserving the moisture content of the skin. The levels of these proteins decrease during the aging process as the results of increased dermal enzymatic activities, such as collagenase, elastase, tyrosinase, and hyaluronidase (Widowati et al., 2018).

Chronological aging cannot be postponed. Photoaging and aging caused by free radicals can be handled by administering materials or compounds with antioxidant properties. Antioxidants are used to avoid aging due to their capacity to suppress the activity and expression of Matrix Metalloproteinases (MMPs) (Madan and Nanda, 2018). The abilities of natural compounds like flavonoids and phenols to scavenge free radicals are confirmed (Yang et al., 2008). Many studies have elucidated the biological activities of flavonoids and phenols, including as antioxidants (Rusmana et al., 2017), antivirals, anti-inflammatory agents (Harborne and Williams, 2000), and antiaging (Taofiq et al., 2016; Widowati et al., 2016, 2017, 2018).

Rutin and caffeic acid have been detected in snake fruit peels (Salacca zalacca (Gaert.) Voss) by molecular docking (in silico) analysis (Girsang, Ginting, et al., 2019) and LCESI-MS (Girsang, Lister, et al., 2019). Rutin is part of the flavonoid glycoside group, commonly known as vitamin P, and has antihypertensive and antiviral potentials, as evident from its capability of scavenging free radicals (Yang et al., 2008). Caffeic acid (3,4-dihydroxycinnamic acid) is a member of the phenolics class that contains methoxy and hydroxyl on its structure (Khan et al., 2016).

Previous studies of rutin and caffeic acid as antioxidants are in silico, while this research was conducted to determine their potency both as antioxidants and antiaging by in vitro. Furthermore, these compounds were measured from their capacity to inhibit the aging process and scavenge free radicals. Also, this research evaluated the efficacy of rutin and caffeic acid as antioxidants by 2,2-diphenyl-1picrylhydrazil (DPPH), $\mathrm{H}_{2} \mathrm{O}_{2}, 2,2$ '-azinobis-3-ethylbenzo-thiazoline-6-sulfonic acid (ABTS), and ferric reducing antioxidant power (FRAP) assays and as antiaging agents by the elastase, tyrosinase, collagenase, and hyaluronidase inhibitory assays.

\section{MATERIALS AND METHOD}

\section{Materials}

\section{Antioxidant Assay}

Caffeic acid (Chengdu Biopurify Phytochemicals Ltd, BP0300), rutin (Chengdu Biopurify Phytochemicals Ltd, BP1234), DMSO (Sigma-Aldrich, 1060092500), DPPH (Sigma-Aldrich, D9132), ferrous ammonium sulfate (Sigma-Aldrich, 7783859), $\mathrm{H}_{2} \mathrm{O}_{2}$ (Sigma-Aldrich, 1085971000), 1,10-phenanthroline (Sigma-Aldrich, 131377), ABTS $^{++}$(Sigma-Aldrich, A1888), potassium persulfate $\left(\mathrm{K}_{2} \mathrm{~S}_{2} \mathrm{O}_{8}\right)$ (Sigma-Aldrich, EM105091), $\mathrm{FeCl}_{3} \cdot 6 \mathrm{H}_{2} \mathrm{O}$ (Sigma-Aldrich, 1039430250), 2,4,6- 
Tris(2-pyridyl)-s-triazine (TPTZ) (Sigma-Aldrich, T1253), and Collagenase from Clostridium histolyticum (Sigma-Aldrich, C8051).

\section{Antiaging Assay}

N-[3-(2-Furyl)acryloyl]-leu-gly-Pro-Ala substrate (Sigma-Aldrich, F5135), elastase from porcine pancreas $\left(0.5 \mathrm{mU} / \mathrm{ml}\right.$ in cold $\mathrm{ddH}_{2} \mathrm{O}$, Sigma-Aldrich, 45124), tyrosinase from mushroom enzymes (125 U/mL, Sigma-Aldrich, T3824), L-DOPA substrate (1.5 mM, Sigma-Aldrich, D9628), enzymes hyaluronidase from bovine testes type IS $(0.02 \mathrm{mg} / \mathrm{ml}$, Sigma-Aldrich, H3506), and phosphate buffer (300 mM, pH 5.35, Sigma-Aldrich, 0751).

\section{Tools}

Microplate reader (Multiskan ${ }^{\mathrm{TM}}$ GO Microplate, Thermo Scientific), 96-well plate (TPP, 92096), incubator (ESCO, IFA-32-8), micropipette (Eppendorf), tips (Neptune), vortex (WiseMix, VM-10), $1.5 \mathrm{~mL}$ microtube (SPL, 60015-1), and $15 \mathrm{ml}$ Falcon tube (SPL).

\section{Methods}

\section{DPPH scavenging assay}

The DPPH scavenging activity was gauged according to the method employed in Rusmana et al. (2017), Widowati et al. (2018), Siregar et al. (2019), and Vrianty et al. (2019). Fifty $\mu$ l of samples at various concentrations (15.6-250 $\mu \mathrm{g} / \mathrm{ml}$ in DMSO 1\%) was poured into each well in the 96-well plate, mixed with $200 \mu \mathrm{l}$ of DPPH solution $(0.077 \mathrm{mmol} / \mathrm{l})$, and then incubated in a dark room with room temperature (RT) for $30 \mathrm{~min}$. Afterward, the mixture absorbance was scanned using a microplate reader at $517 \mathrm{~nm}$ and expressed as a percentage of DPPH scavenging activity, which was calculated using the equation below:

$$
\% \text { DPPH Scavenging Activity }=(1-(\text { As/Ac })) \times 100
$$

Ac: Absorbance of negative control As: Sample absorbance

\section{$\mathrm{H}_{2} \mathrm{O}_{2}$ scavenging assay}

The method employed by Asan et al. (2019), Jusri et al. (2019), Liana et al. (2019), and Utami et al. (2017) to measure $\mathrm{H}_{2} \mathrm{O}_{2}$ scavenging activities was used with modifications. Ferrous ammonium sulfate $(1 \mathrm{mM}, 12 \mu \mathrm{l})$ and samples at various concentrations $(7.81-250 \mu \mathrm{g} / \mathrm{ml}, 60 \mu \mathrm{l}), \mathrm{H}_{2} \mathrm{O}_{2}(5 \mathrm{mM}, 3$ $\mu \mathrm{l})$ were transferred into a 96 -well plate and incubated at room temperature for $5 \mathrm{~min}$. Then, $75 \mu \mathrm{l}$ of 1,10-phenanthroline was added, and the plate was incubated again for 10 minutes in the same condition. The mixture absorbance was read using a microplate reader at a wavelength of $510 \mathrm{~nm}$ and expressed as a percentage of $\mathrm{H}_{2} \mathrm{O}_{2}$ scavenging activity, which was computed using the equation below:

$$
\% \mathrm{H}_{2} \mathrm{O}_{2} \text { Scavenging Activity }=(1-(\mathrm{As} / \mathrm{Ac})) \times 100
$$

Ac: Absorbance of negative control

As: Sample absorbance

\section{ABTS scavenging assay}

Briefly, $2 \mu$ l of samples at various concentrations were put into a 96-well plate, mixed with 198 $\mu \mathrm{l}$ of $\mathrm{ABTS}^{\circ+}$ solution, and then incubated at $37^{\circ} \mathrm{C}$ for 6 minutes. Afterward, the absorbance values of these samples were gauged using a microplate reader at a wavelength of $745 \mathrm{~nm}$ (Geeta et al., 2019; Widowati et al., 2016, 2017, 2018). The equation below was used to calculate the ABTS scavenging activity: 
$\%$ ABTS Reducing Activity $=(1-(\mathrm{As} / \mathrm{Ac})) \times 100$

Ac: Absorbance of negative control

As: Sample absorbance

\section{FRAP assay}

The FRAP assays of rutin and caffeic acid were prepared following the method employed by Rusmana et al. (2017) and Widowati et al. (2016, 2017, 2018). The reagent was prepared by mixing ferric chloride hexahydrate $(20 \mathrm{mM}, 1 \mathrm{~mL})$, acetate buffer $(\mathrm{pH} 3.6,300 \mathrm{mM}$ that conformed with supplemental acetic acid, $10 \mathrm{~mL})$, and TPTZ $(10 \mathrm{mM}, 1 \mathrm{~mL})$. In each well of the 96-well plate, $7.5 \mu 1$ of samples at various concentrations was mixed with $142.5 \mu \mathrm{l}$ of FRAP reagent, then incubated at $37^{\circ} \mathrm{C}$ for $30 \mathrm{~min}$. A microplate reader was used to ascertain the absorbance of this mixture at $593 \mathrm{~nm}$. The ferrous reducing activity of the samples was calculated using the $\mathrm{FeSO}_{4}$ standard curve, starting from the concentration of 1.56 until $50 \mu \mathrm{g} / \mathrm{mL}$, then the data obtained were presented in $\mu \mathrm{M} \mathrm{Fe}$ (II) $/ \mu \mathrm{g}$ extract.

\section{Collagenase inhibitory assay}

This assay was the updated procedure of Geeta et al. (2019) and Widowati et al. (2016, 2017, 2018). Shortly, collagenase from Clostridium histolyticum (0.01 U/mL in cold aquadest, $10 \mu \mathrm{l})$, Tricine buffer $\left(50 \mathrm{mM}, \mathrm{pH} 7.5\right.$, containing $10 \mathrm{mM} \mathrm{CaCl}_{2}$ and $\left.400 \mathrm{mM} \mathrm{NaCl}, 6 \mu \mathrm{l}\right)$, and the sample $(4.69-150 \mu \mathrm{g} / \mathrm{mL}, 30 \mu \mathrm{l})$ was transferred to a 96 -well plate and incubated at $37^{\circ} \mathrm{C}$ for 20 min. Then, this mixture was added with $20 \mu$ of the FALGPA substrate ( $1 \mathrm{mM}$ in Tricine buffer). The absorbance was measured using a microplate reader at $335 \mathrm{~nm}$ and inputted to the formula below:

$$
\% \text { Collagenase Inhibitory Activity }=(1-(\mathrm{As} / \mathrm{Ac})) \times 100
$$

Ac: Absorbance of negative control

As: Sample absorbance

\section{Elastase inhibitory assay}

The inhibitory activity of elastase was examined following the procedure described in Widowati et al. $(2016,2017,2018)$ with modifications. Approximately $10 \mu \mathrm{l}$ of samples $(2.08-66.67 \mu \mathrm{g} / \mathrm{ml}) \mathrm{was}$ pre-incubated at room temperature for 15 minutes, then added with $5 \mu$ of elastase $(0.5 \mathrm{mU} / \mathrm{mL}$ in cold $\left.\mathrm{ddH}_{2} \mathrm{O}\right)$ and $125 \mu \mathrm{l}$ of Tris buffer $(\mathrm{pH} 8,100 \mathrm{mM})$. Afterward, the mixture was added with $10 \mu \mathrm{l}$ of $\mathrm{C}_{19} \mathrm{H}_{25} \mathrm{~N}_{5} \mathrm{O}_{8}$ substrate ( $2 \mathrm{mg} / \mathrm{mL}$ in Tris buffer) and incubated for 15 minutes at room temperature. The absorbance was scanned using a spectrophotometer at $410 \mathrm{~nm}$, and the percent elastase inhibitory activity was calculated using the formula below:

$$
\% \text { Elastase Inhibitory Activity }=(1-(\mathrm{As} / \mathrm{Ac})) \times 100
$$

Ac: Absorbance of negative control

As: Sample absorbance

\section{Tyrosinase inhibitory assay}

This assay was carried out using the modified method of Siregar et al. (2019) and Vrianty et al. (2019). Samples at various concentrations $(0.78-50 \mu \mathrm{g} / \mathrm{mL}, 20 \mu \mathrm{l})$, tyrosinase from mushroom enzymes $(20 \mu \mathrm{l})$, and potassium phosphate buffer $(\mathrm{pH} 6.8,140 \mu \mathrm{l})$ were incubated at room temperature for $15 \mathrm{~min}$. Furthermore, the controls were prepared by mixing enzymes $(20 \mu \mathrm{l})$ with phosphate buffers $(160 \mu \mathrm{l})$, while the blanks were created by combining phosphate buffers $(160 \mu \mathrm{l})$ and the samples $(20 \mu \mathrm{l})$. Then, a combination of the L-DOPA substrate $(20 \mu \mathrm{l})$ was applied to the mixture of the samples, control, and blank and re-incubated at room temperature for $10 \mathrm{~min}$. The absorbance was 
scanned at $470 \mathrm{~nm}$ and used to compute the percentage of tyrosinase inhibitory activity using the equation:

$$
\% \text { Tyrosinase Inhibitory Activity }=(1-(\mathrm{As} / \mathrm{Ac})) \times 100
$$

Ac: Absorbance of negative control

As: Sample absorbance

\section{Hyaluronidase inhibitory assay}

This activity was estimated using a method that had been previously employed by Asan et al. (2019), Jusri et al. (2019), Liana et al., (2019) and Widowati et al. (2016, 2017, 2018). A mixture containing samples $(0.78-50 \mu \mathrm{g} / \mathrm{mL}, 25 \mu \mathrm{l})$, phosphate buffer $(12 \mu \mathrm{l})$, and the enzyme hyaluronidase (3 $\mu \mathrm{l})$ was incubated at $37^{\circ} \mathrm{C}$ for $10 \mathrm{~min}$. Afterward, the control solution containing enzymes $(3 \mu \mathrm{l})$ and phosphate buffers $(37 \mu \mathrm{l})$ and the blank prepared with phosphate buffers $(15 \mu \mathrm{l})$ and samples $(25 \mu \mathrm{l})$ were incubated in the same condition. Then, $10 \mu \mathrm{l}$ of the hyaluronic acid combination was added to the mixture of samples, control, and blank and stored at $37^{\circ} \mathrm{C}$ for $45 \mathrm{~min}$. The Stop Solution consisting of $100 \mu \mathrm{l}$ of acidic albumin ( $24 \mathrm{mM}$ sodium acetate, $0.1 \% \mathrm{BSA}$, and $79 \mathrm{mM}$ acetate acid) was added into the solution and left at room condition for $10 \mathrm{~min}$. The absorbance was calculated using a spectrophotometer at $600 \mathrm{~nm}$ and inputted to the equation below:

$$
\% \text { Hyaluronidase Inhibitory Activity }=(1-(\mathrm{As} / \mathrm{Ac})) \times 100
$$

Ac: Absorbance of negative control

As: Sample absorbance

\section{Statistical analysis}

The data obtained from the above assays were processed statistically by analysis of variance (One Way ANOVA) and post hoc Tukey's Honest Significant Difference test in the SPSS program (version 20.0). These analysis were aimed to calculate noticeable dissimilarities among the concentrations of the samples. The $\mathrm{IC}_{50}$ value of each assay (DPPH, $\mathrm{H}_{2} \mathrm{O}_{2}$, ABTS scavenging, and elastase, collagenase, tyrosinase, and hyaluronidase inhibitory) was calculated based on the curve standard.

\section{RESULTS AND DISCUSSION}

The antioxidant activities of rutin and caffeic acid were investigated by the DPPH, $\mathrm{H}_{2} \mathrm{O}_{2}$, FRAP, and ABTS assays, as shown in Table 1 and Figure 1.

Table 1. The $\mathrm{IC}_{50}$ values representing the antioxidant activities of rutin and caffeic acid

\begin{tabular}{ccccc}
\hline Assays & Samples & $\begin{array}{c}\text { The strongest activity at the } \\
\text { highest concentration }\end{array}$ & $\mathbf{R}^{\mathbf{2}}$ & $\mathbf{I C}_{\mathbf{5 0}}(\boldsymbol{\mu g} / \mathbf{m l})$ \\
\hline & & & & \\
DPPH Scavenging & Rutin & $91.22 \pm 0.36(\%)$ & 0.96 & $5.79 \pm 0.82$ \\
Activity & Caffeic Acid & $90.37 \pm 0.17(\%)$ & 0.95 & $8.72 \pm 0.43$ \\
$\mathrm{H}_{2} \mathrm{O}_{2}$ Scavenging & Rutin & $101.01 \pm 1.16(\%)$ & 0.95 & $12.9 \pm 0.77$ \\
Activity & Caffeic Acid & $85.59 \pm 0.49(\%)$ & 0.96 & $15.23 \pm 2.11$ \\
ABTS Scavenging & Rutin & $80.26 \pm 0.38(\%)$ & 0.96 & $16.59 \pm 0.18$ \\
Activity & Caffeic Acid & $82.21 \pm 0.86(\%)$ & 0.99 & $6.23 \pm 1.24$ \\
FRAP & Rutin & $480.08 \pm 6.63(\mu \mathrm{M} \mathrm{Fe}(\mathrm{II}) / \mu \mathrm{g})$ & - & - \\
& Caffeic Acid & $526.50 \pm 8.30(\mu \mathrm{M} \mathrm{Fe}(\mathrm{II}) / \mu \mathrm{g})$ & - & - \\
\hline
\end{tabular}

The data are presented in mean \pm standard deviation. The assays were run in triplicate. The coefficient of regression $\left(\mathrm{R}^{2}\right)$ and the $\mathrm{IC}_{50}$ of each sample were calculated by linear regression. 

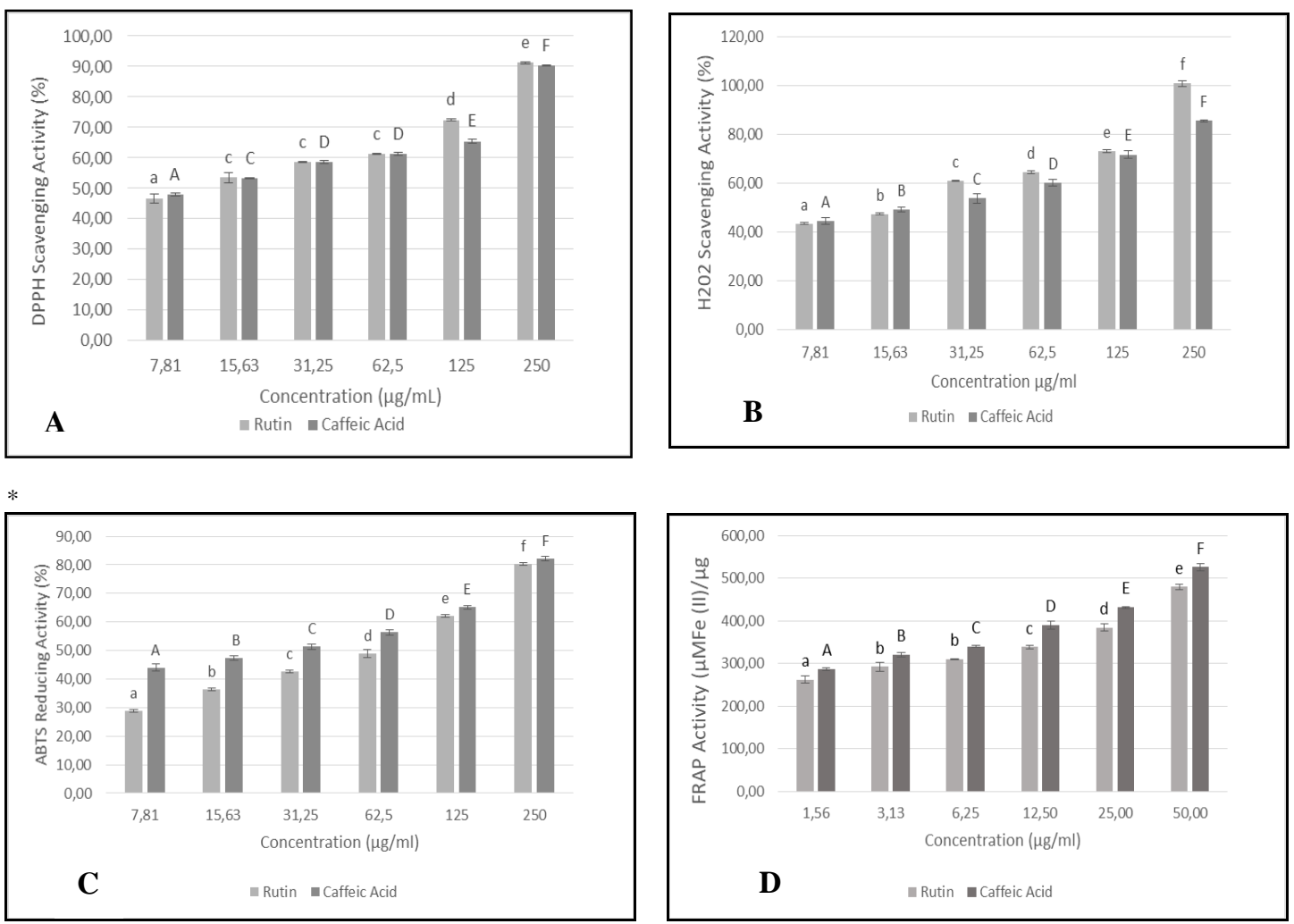

Figure 1. The effects of rutin and caffeic acid at different concentrations $(\mu \mathrm{g} / \mathrm{ml})$ on $(\mathrm{A}) \mathrm{DPPH},(\mathrm{B}) \mathrm{H}_{2} \mathrm{O}_{2}$, (C)ABTS, and (D)ferric ions (FRAP)

The data are presented in mean \pm standard deviation. Different letters above every bar chart indicate significant differences between the sample concentrations tested in each antioxidant assay of rutin and caffeic acid.

The antioxidant activities of rutin and caffeic acid were concentration-dependent; in other words, when applied at higher concentrations, their activities are most likely to escalate. Also, all concentrations showed a significant difference between the antioxidant activities of rutin and caffeic acid $(\mathrm{P}<0.05)$. The $\mathrm{IC}_{50}$ values of rutin and caffeic acid, as obtained from the antioxidant assays (i.e., DPPH and $\mathrm{H}_{2} \mathrm{O}_{2}$ scavenging activity, ABTS-reducing activity, and highest FRAP), are presented in Table 1. Figure 2 shows the antiaging activities of rutin and caffeic acid, as drawn from the investigation results of the collagenase, elastase, tyrosinase, and hyaluronidase inhibition. 



Figure 2. The inhibitory effects of rutin and caffeic acid at different concentrations ( $\mu \mathrm{g} / \mathrm{mL})$ against (A)elastase, (B)hyaluronidase, (C)collagenase, and (D)tyrosinase

The data are presented in mean \pm standard deviation. Different letters above every bar chart indicate significant differences between the sample concentrations tested in each antiaging assay of rutin and caffeic acid.

The antiaging activities of rutin and caffeic acid were concentration-dependent, i.e., when applied at a higher concentration, both compounds increased the inhibition activity. The $\mathrm{IC}_{50}$ values of rutin and caffeic acid, as obtained by the antiaging assays (i.e., the inhibitory activities against hyaluronidase, elastase, collagenase, and tyrosinase), are shown in Table 2.

Table 2. The $\mathrm{IC}_{50}$ values representing the antiaging activities of rutin and caffeic acid

\begin{tabular}{lccc}
\hline \multicolumn{1}{c}{ Assays } & Samples & $\mathbf{R}^{\mathbf{2}}$ & $\mathbf{I C}_{\mathbf{5 0}}(\boldsymbol{\mu g} \mathbf{g} \mathbf{m L})$ \\
\hline \multirow{2}{*}{ Collagenase Inhibition } & Rutin & 0.98 & $104.7 \pm 0.69$ \\
& Caffeic Acid & 0.95 & $74.42 \pm 19.6$ \\
Elastase Inhibition & Rutin & 0.97 & $46.88 \pm 1.031$ \\
& Caffeic Acid & 0.98 & $76.95 \pm 3.51$ \\
Tyrosinase Inhibition & Rutin & 0.97 & $55.65 \pm 0.98$ \\
& Caffeic Acid & 0.99 & $145.91 \pm 2.74$ \\
Hyaluronidase Inhibition & Rutin & 0.97 & $114.07 \pm 3.83$ \\
& Caffeic Acid & 0.97 & $244.45 \pm 37.69$ \\
\hline
\end{tabular}

*The $\mathrm{IC}_{50}$ values are presented in mean \pm standard deviation. All experiments were run in triplicate. The coefficient of regression $\left(\mathrm{R}^{2}\right)$ and the $\mathrm{IC}_{50}$ value of each sample were calculated based on linear regression. 
Skin aging processes through wrinkle formation, antioxidant system destruction, and melanogenesis due to continuous ROS exposures have been documented (Widowati et al., 2016). Extracellular matrix (ECM), such as elastin, tyrosine, collagen, and hyaluronic acid, is considered to be specifically impacted by aging factors as it is degraded mostly by free radicals during the aging process. According to Papakonstantinou et al. (2012), ROS also induces the transcription factors of MAPK (c-Jun via mitogen-activated protein kinases), leading to overexpression of MMP-9, MMP-1, and MMP-3 and inhibited expression of procollagen-1.

Phenolics and flavonoids are a class of compounds derived from plants and are said to have free radical scavenging ability due to their stable structures even after housing the free radicals (Khan et al., 2016). Moreover, since the skin aging process involves ROS, antioxidants can act as antiaging substances by various mechanisms, including metal chelation, protein binding, free radical scavenging (Masek et al., 2016; Widowati et al., 2016, 2017, 2018). Flavonoids and phenols derived from plants can create metal ion complexes, meaning that they can bind to metalloenzymes (Thring et al., 2009).

Rutin is a pure compound classified as flavonoid, which is commonly found in vegetables, fruits, and snake fruit peels (Girsang, Ginting, et al., 2019; Girsang, Lister, et al., 2019). It contains vicinyl dihydroxyl groups that can inhibit $\mathrm{Fe}$ and $\mathrm{Cu}$-catalyzed free radical growth (Yang et al., 2008). Rutin has an ortho-dihydroxyl group in its B-ring and sugars at three positions, all of which underly its strong free radical scavenging properties (Sintayehu et al., 2012). Based on the experiment, rutin has DPPH and $\mathrm{H}_{2} \mathrm{O}_{2}$ scavenging capacities better than caffeic acid. This finding is consistent Bastianini et al. (2018) and Rusmana et al. (2017), which successfully detected the antioxidant potential of rutin. Cervantes-Laurean et al. (2006) suggest that flavonoids with vicinyl dihydroxyl groups in the B-ring inhibit iron and copper-catalyzed radical species growth. On the other hand, caffeic acid possesses more effective ferrous and ABTS-reducing activities than rutin. According to Genaro-Mattos et al. (2015), caffeic acid can complex Fe (II) ions by $\mathrm{pH}$ modification, i.e., an increase in the $\mathrm{pH}$ of the medium elevates the capability of caffeic acid to chelate the metal. Besides, the antioxidant activity of polyphenols is highly dependent on the position, structure, and number of hydroxyl groups. Caffeic acid has two hydroxyl $(\mathrm{OH})$ groups (Masek et al., 2016), while rutin has five $\mathrm{OH}$ groups in the ring, making it easier to oxidize.

Rutin and caffeic acid exhibited antiaging activities through the inhibitions of collagenase, tyrosinase, elastase, and hyaluronidase. This finding is consistent with (Girsang, Ginting, et al., 2019), which confirm the potentials of rutin and caffeic acid found in snake fruit peels to attach to proteins responsible for the aging processes, namely Polyphenol Oxidase 3 (PPO3), MMP1, and Neutral Endopeptidase (NEP) and the competitive form of enzyme inhibition by molecular docking in the skin aging process. Rutin has been reported to inhibit aging-related mitochondrial dysfunction in aged test rats by increasing oxygen consumption rate, GSH content, and SOD activity, signifying its antioxidant and antiaging potential (Li et al., 2016). Caffeic acid is the most promising antioxidant, antiinflammatory, and anti-wrinkle agent (Bastianini et al., 2018).

\section{CONCLUSION}

Rutin has DPPH and $\mathrm{H}_{2} \mathrm{O}_{2}$ scavenging activities and elastase, tyrosinase, and hyaluronidase inhibitory activities that are better than caffeic acid. Meanwhile, caffeic acid has more potent ABTS scavenging activity, FRAP, and collagenase inhibitory activity.

\section{ACKNOWLEDGMENT}

The authors thankfully acknowledge Universitas Prima Indonesia, Medan-Indonesia, for funding this research and Aretha Medika Utama (the Biomolecular and Biomedical Research Center, Bandung-Indonesia) for permitting the use of laboratory facilities and methodology. The authors would also like to thank Hanna Sari Widya Kusuma, Rr. Anisa Siwianti Handayani, Dwi Surya Artie, Dewani Tediana Yusepany for their invaluable assistance. 


\section{REFERENCES}

Asan, T., Lister, I. N. E., Fachrial, E., Amalia, A., Widowati, W., Samin, B., \& Liena, L. (2019). Potency of black soybean (Glycine $\max (\mathrm{L}$.) Merr) extract and daidzein as antioxidant and antihyaluronidase. Majalah Obat Tradisional, 24(1), 52-58. https://doi.org/10.22146/mot.43615

Bastianini, M., Faffa, C., Sisani, M., \& Petracci, A. (2018). Caffeic acid-layered double hydroxide hybrid: a new raw material for cosmetic applications. Cosmetics, 5(3), 51. https://doi.org/10.3390/cosmetics5030051

Cervantes-Laurean, D., Schramm, D. D., Jacobson, E. L., Halaweish, I., Bruckner, G. G., \& Boissonneault, G. A. (2006). Inhibition of advanced glycation end product formation on collagen by rutin and its metabolites. The Journal of Nutritional Biochemistry, 17(8), 531-540. https://doi.org/10.1016/j.jnutbio.2005.10.002

Farage, M. A., Miller, K. W., Berardesca, E., \& Maibach, H. I. (2009). Clinical implications of aging skin. American Journal of Clinical Dermatology, 10(2), 73-86. https://doi.org/10.2165/00128071-200910020-00001

Geeta, Widodo, W. S., Widowati, W., Ginting, C. N., Lister, I. N. E., Armansyah, A., \& Girsang, E. (2019). Comparison of antioxidant and anti-collagenase activity of genistein and epicatechin. Pharmaceutical Sciences and Research, 6(2), 111-117. https://doi.org/10.7454/psr.v6i2.4510

Genaro-Mattos, T. C., Maurício, Â. Q., Rettori, D., Alonso, A., \& Hermes-Lima, M. (2015). Correction: Antioxidant activity of caffeic acid against iron-induced free radical generation-a chemical approach. Plos One, 10(6), e0129963. https://doi.org/10.1371/journal.pone.0129963

Girsang, E., Ginting, C. N., Ehrich Lister, I. N., Widowati, W., Wibowo, S. H. B., Perdana, F. S., \& Rizal, R. (2019). In silico analysis of phytochemical compound found in snake fruit (Salacca zalacca) peel as anti-aging agent. Thai Journal of Pharmaceutical Sciences, 43(2), 105-109.

Girsang, E., Lister, I. N. E., Ginting, C. N., Khu, A., Samin, B., Widowati, W., Wibowo, S., \& Rizal, R. (2019). Chemical Constituents of snake fruit (Salacca zalacca (Gaert.) Voss) peel and in silico antiaging analysis. Molecular and Cellular Biomedical Sciences, 3(2), 122. https://doi.org/10.21705/mcbs.v3i2.80

Harborne, J. B., \& Williams, C. A. (2000). Advances in flavonoid research since 1992. Phytochemistry, 55(6), 481-504. https://doi.org/10.1016/S0031-9422(00)00235-1.

Jusri, R., Widodo, W. S., Widowati, W., Armansyah, A., Sormin, D. E., Fachrial, E., \& Lister, I. N. E. (2019). Comparison of antioxidant and anti-hyaluronidase potentials of pineapple core extract (Ananas comosus (L.) Merr.) and luteolin. Majalah Kedokteran Bandung, 51(2), 63-69. https://doi.org/10.15395/mkb.v51n2.1629.

Khan, F. A., Maalik, A., \& Murtaza, G. (2016). Inhibitory mechanism against oxidative stress of caffeic acid. Journal of Food and Drug Analysis, 24(4), 695-702. https://doi.org/10.1016/j.jfda.2016.05.003

Li, T., Chen, S., Feng, T., Dong, J., Li, Y., \& Li, H. (2016). Rutin protects against aging-related metabolic dysfunction. Food \& Function, 7(2), 1147-1154. https://doi.org/10.1039/C5FO01036E

Liana, L., Rizal, R., Widowati, W., Fioni, F., Akbar, K., Fachrial, E., \& Lister, I. N. E. (2019). Antioxidant and anti-hyaluronidase activities of dragon fruit peel extract and kaempferol-3-O rutinoside. Jurnal Kedokteran Brawijaya, 30(4), 247-252. https://doi.org/10.21776/ub.jkb.2019.030.04.3.

Madan, K., \& Nanda, S. (2018). In-vitro evaluation of antioxidant, anti-elastase, anti-collagenase, antihyaluronidase activities of safranal and determination of its sun protection factor in skin photoaging. Bioorganic Chemistry, 77(1), 159-167. https://doi.org/10.1016/j.bioorg.2017.12.030

Masek, A., Chrzescijanska, E., \& Latos, M. (2016). Determination of antioxidant activity of caffeic acid and p-coumaric acid by using electrochemical and spectrophotometric assays. International Journal of Electrochemical Science, 11(1), 10644-10658. https://doi.org/10.20964/2016.12.73.

Onar, H. C., Yusufoglu, A., Turker, G., \& Yanardag, R. (2012). Elastase, tyrosinase and lipoxygenase inhibition and antioxidant activity of an aqueous extract from Epilobium angustifolium L. leaves. Journal of Medicinal Plants Research, 6(5), 716-726. https://doi.org/10.5897/JMPR11.1127. 
Palmer, D. M., \& Kitchin, J. S. (2010). Oxidative damage, skin aging, antioxidants and a novel antioxidant rating system. Journal of Drugs in Dermatology, 9(1), 11-15.

Papakonstantinou, E., Roth, M., \& Karakiulakis, G. (2012). Hyaluronic acid: a key molecule in skin aging. Dermato-Endocrinology, 4(3), 253-258. https://doi.org/10.4161/derm.21923

Riani, M. K. L., Anwar, E., \& Nurhayati, T. (2018). Antioxidant and anti-collagenase activity of Sargassum plagyophyllum extract as an anti-wrinkle cosmetic ingredient. Pharmacognosy Journal, 10(5), 932-936. https://doi.org/10.5530/pj.2018.5.157.

Rusmana, D., Wahyudianingsih, R., Elisabeth, M., Balqis, B., Maesaroh, M., \& Widowati, W. (2017). Antioxidant activity of Phyllanthus niruri extract, rutin and quercetin. The Indonesian Biomedical Journal, 9(2), 84-90. https://doi.org/10.18585/inabj.v9i2.281.

Sintayehu, B., Asres, K., \& Raghavendra, Y. (2012). Radical scavenging activities of the leaf extracts and a flavonoid glycoside isolated from Cineraria abyssinica Sch. Bip. Exa. Rich. Journal of Applied Pharmaceutical Science, 2(4), 44-49. https://doi.org/10.7324/JAPS.2012.2407.

Siregar, I. D., Kusuma, H. S. W., Widowati, W., Marpaung, H. H., Ferdinand, S., Fachrial, E., \& Lister, I. N. E. (2019). Antioxidant and antityrosinase activities of ethanolic Pachyrhizus erosus peel and tuber extract. Majalah Kedokteran Bandung, 51(2), 75-81. https://doi.org/10.15395/mkb.v51n2.1628.

Taofiq, O., González-Paramás, A. M., Martins, A., Barreiro, M. F., \& Ferreira, I. C. F. R. (2016). Mushrooms extracts and compounds in cosmetics, cosmeceuticals and nutricosmetics-a review. Industrial Crops and Products, 90, 38-48. https://doi.org/10.1016/j.indcrop.2016.06.012.

Thring, T. S., Hili, P., \& Naughton, D. P. (2009). Anti-collagenase, anti-elastase and anti-oxidant activities of extracts from 21 plants. BMC Complementary and Alternative Medicine, 9(1), 27. https://doi.org/10.1186/1472-6882-9-27.

Utami, S., Adityaningsari, P., Sosiawan, I., Endrini, S., Sachrowardi, Q. R., Laksono, S. P., Nafik, S., Arrahmani, B. C., Afifah, E., \& Widowati, W. (2017). Antioxidants and anticholinesterase activities of the characterized ethanolic of ripe sesoot (Garcinia picrorrhiza Miq.) fruit extract (GpKar) and xanthone. Majalah Obat Tradisional, 22(3), 160-165. https://doi.org/10.22146/mot.31548.

Vrianty, D., Qodariah, R. L., Widowati, W., Sinaga, A. P. F., Fibrina, D., Fachrial, E., \& Lister, I. N. E. (2019). Comparison of Antioxidant and anti-tyrosinase activities of pineapple (Ananas comosus) core extract and luteolin compound. Jurnal Kedokteran Brawijaya, 30(4), 240. https://doi.org/10.21776/ub.jkb.2019.030.04.2.

Widowati, W., Fauziah, N., Herdiman, H., Afni, M., Afifah, E., Kusuma, H. S. W., Nufus, H., Arumwardana, S., \& Rihibiha, D. D. (2016). Antioxidant and antiaging assays of Oryza sativa extracts, vanilin, and coumaric acid. Journal of Natural Remedies, 16(3), 88-99. https://doi.org/10.18311/jnr/2016/7220.

Widowati, W., Rani, A. P., Hamzah, R. A., Arumwardana, S., Afifah, E., Kusuma, H. S. W., Rihibiha, D. D., Nufus, H., \& Amalia, A. (2017). Antioxidant and antiaging assays of Hibiscus sabdariffa extract and its compounds. Natural Product Sciences, 23(3), 192. https://doi.org/10.20307/nps.2017.23.3.192.

Widowati, W., Widya Janeva, B., Nadya, S., Amalia, A., Arumwardana, S., Kusuma, H. S. W., \& Arinta, Y. (2018). Antioxidant and antiaging activities of Jasminum sambac extract, and its compounds. Journal of Reports in Pharmaceutical Sciences, 7(3), 270-285.

Yang, J., Guo, J., \& Yuan, J. (2008). In vitro antioxidant properties of rutin. LWT - Food Science and Technology, 41(6), 1060-1066. https://doi.org/10.1016/j.lwt.2007.06.010. 